\title{
Analysis of barriers and drivers for BIM adoption.
}

\author{
HAMMA-ADAMA, M., KOUIDER, T. and SALMAN, H.
}


International Journal of BIM and Engineering Science

BIM

Volume: 3 Issue: 1; Jun - 2020; Page: 18-41

ISSN 2571-1075

\title{
Analysis of Barriers and Drivers for BIM Adoption
}

\author{
Mansur Hamma-adama*1, 2, Tahar Kouider', Huda Salman' \\ ${ }^{1}$ Robert Gordon University, UK, ${ }^{2}$ Kaduna Polytechnic, Nigeria \\ m.hamma-adama@rgu.ac.uk, t.kouider@rgu.ac.uk, h.salman@rgu.ac.uk
}

\begin{abstract}
:
Research on 'digitalization and collaboration' in the construction industry has been gaining momentum in the recent academic engagements. Despite its existence in many industries (i.e. financial services, retailing, publishing and travelling) for over ten years, it is yet to catch up by the construction market; this is due to several challenges whose existence are more dynamic and contextual than generic to various countries. The problems are defined in many studies across borders, but their impacts varied with countries. This case is equally the same to drivers toward the adoption of BIM. This study analyses barriers and drivers to BIM adoption in the Nigerian construction industry from adopters and nonadopters perspectives as to allow an informed decision in developing a strategy for macro BIM adoption. Primary data fetched from professional stakeholders through an online questionnaire survey were analysed using SPSS software and Microsoft Excel. This investigation reveals the most significant barriers against BIM adoption as Lack of expertise, Lack of standardization and protocols to mention but a few. And, most influential drivers from both adopters and non-adopters as Availability of trained professionals to handle the tools, Proof of cost savings by its adoption, BIM Software affordability, and awareness of the technology among the industry stakeholders. The adopters and non-adopters groups have nearly equal Percentage Disagreement (PD) and Percentage Agreement (PA) for both the barriers and drivers to BIM adoption. Thus, this suggests that the adopters are still at the early stage of BIM adoption, so have nearly the same perceptions with the non-adopters. The study recommends proper consideration of the established barriers and drivers while developing any strategy for effective BIM adoption. Further face-to-face (interview) study is necessary to explore more and in-depth challenges to adoption of BIM in the industry; and as the industry is getting more aware of the BIM, periodic evaluation of the critical barriers and drivers is vital.
\end{abstract}

Keywords: BIM adoption; BIM barriers; BIM drivers; construction industry; Nigeria.

*Corresponding author. Tel.: +447774857145; +2348037667944.

E-mail address: m.hamma-adama@rgu.ac.uk 


\section{Introduction:}

Building Information Modelling (BIM) is a digital model representing physical and functional characteristics of building or infrastructure (BIM Industry Working Group 2011). Chartered Institute of Builder (CIOB) described the fundamental idea behind the BIM as to create and share the right information at the right time throughout the design, construction and operation of a building or facility to improve efficiency and decision making. This new paradigm shift in the construction industry is gaining high recognition both in the academic discuss (research) and the industry (application). However, its universal adoption is facing common challenges but yet persistent within the industry and across the world. These challenges are more the same rather than different; although their significance and uniqueness vary with country. On the other hand, the drivers that facilitate its adoption have a similar trend with the barriers.

The BIM is similar to other technologies or innovations; it comes with challenges and barriers while adoption and implementation (McAdam, 2010). Barnes and Davies (2015) revealed the most perceived barriers against BIM adoption by organizations as an issue of readiness, high cost of training, and cost of technology investment (hardware and software). This readiness could be the ability to agreeing to change (i.e. awareness driven) or technology and human resources readiness. The construction industry is widely known to be conventional and resistive to changes (Walasek and Barszcz, 2017); although, this new technological process has come to stay.

Eadie et al. (2014) worked on the identification of barriers to BIM adoption and their order of importance, this study reveals so much to the UK BIM adoption strategy and more importantly directing to the most significant barriers to allow adopters pay more attention to them. However, solving one or more barriers without considering the rest may not bring the end to the challenges on adoption (Lindblad, 2013). Studies on barriers and drivers to adoption of BIM revealed many barriers and drivers with differential significance by country (Walasek and Barszcz, 2017; Shaban et al., 2018; Ademci and Gundes, 2018; Elhendawi et al., 2019). A recent study undertaken by Elhendawi et al. (2019) on Kingdom of Saudi Arabian AEC sector where BIM adoption barriers were assessed considering six different categories (personal, technical, business, process, market and organisational barriers). The study holistically revealed personal challenges as the significant barriers to the deployment of BIM. These personal challenges are dominated by a lack of understanding of BIM and its benefits, resistance to change, and lack of BIM education and skills. Similarly, few studies from Nigeria revealed some barriers to BIM adoption (Wang, 2015; Onungwa et al., 2017), but not to common professionals or wide market (macro scale). It is therefore difficult to appraise (at market level) the challenges required to be resolved and drivers to persuade the BIM adoption in the Nigerian construction industry. 
As an extended conference paper (Hamma-adama and Kouider, 2019), this study attempts to fill a gap of differentiating by order of importance, the common barriers and drivers toward BIM adoption from adopters and non-adopters perspectives within the Nigerian construction market. The investigation was set to be achieved through a critical review of literature where potential barriers and drivers for BIM adoption were identified; then ranked by order of significance, and evaluate the adopters and non-adopters perspectives (i.e. the percentage of disagreement). This will allow an informed decision in the development of a strategy to effective BIM adoption within the Nigerian construction market.

\section{Literature review:}

BIM is amongst the most discussed subjects in the Architecture Engineering and Construction (AEC) industry, and perhaps the most discussed area of development in the AEC process. There is a huge development in research and efforts to implement this new innovative process. Hjelseth (2017) compiled five years of publications (2013-2017) from Automation in Construction in the field of BIM; his statistics revealed high $(>70 \%)$ concentration on interoperable technology perspective than collaborative processes. The study suggests more research on awareness of real understanding and how BIM influences AEC activities. On the other hand, some investigators believed that researchers had concentrated mostly on adoption and non-adopters, investigating the barriers and drivers, development of models and frameworks (Hosseini et al., 2016); albeit there is an irregularity in the adoption as well as the implementation across the globe and different disciplines.

There are several investigations and studies on BIM development and usage around the globe. McAuley et al. (2016) mapped the global overview of BIM adoption; Africa is the only continent who does not have representation. Remarkably, there are case studies to learn from at country levels, particularly the countries' BIM adoption trends. Several countries around the world have been striving to preserve the digital shift, for example, USA, UK, Australia, Singapore, South Korea, Denmark, Russia and Finland to mention but a few (McAuley et al., 2016). These countries happened to have bodies that survey the BIM adoption and provide Noteworthy BIM Publications (NBPs) to maintain guide and keep track of the BIM progress. Bodies like BIM Innovation Capability Programme (BICP) - Ireland; National BIM Reports by National Building Specifications - UK; NATSPEC - Australia; and SmartMarket Report by McGraw Hill Construction - USA are examples of these bodies. For a global assessment of BIM adoption and its business value, McGraw Hill Construction remains the only source of NBPs (McAuley et al., 2016).

In the recent academic discussion, there are several investigations on the social aspect of BIM adoption; such as readiness, awareness, level of adoption, capabilities (stages) as well as barriers and driver toward the adoption and implementation of the BIM (Ademci and Gundes, 2018). Such efforts (by countries and organizations) played a significant role in 
revolutionizing the BIM adoption process (Mustaffa et al., 2017). Subsequent studies on BIM adoption challenges revealed consistent trend, from Walasek and Barszcz (2017) to Ademci and Gundes (2018), Sun et al. (2017) and Tan et al. (2019). These studies brought about describing, categorizing, and ranking of barriers against the BIM adoption.

Wang (2015) study also compiled and ranked some challenges faced by Mechanical, Electrical and Plumber (MEP) firms in Nigeria. The study reveals that lack of technical expertise on BIM tools utilization, lack of awareness of BIM technology as well as high cost of investment on staff training, process change, software and hardware upgrade as the most critical barriers to BIM adoption. While Onungwa et al. (2017) revealed lack of skilled personnel, internet connectivity, the reluctance of other stakeholders to use BIM, lack BIM object libraries, and lack of awareness of the technology as the main barriers against BIM adoption. On common grounds, most studies cited and identified challenges in the lack of trained personnel. They are abreast of the latest development in technology also lamented the BIM knowledge gap where most Architects learn on the job, as no training is mostly offered to them.

In the NBS report (2018), barriers to BIM adoption were reported under two umbrellas, internal (i.e. lack of training, expertise and funds to invest), and external (i.e. lack of BIM demand by the client and lack of large projects that necessitate the BIM deployment). While, the most recent compiled barriers by Ademci and Gundes (2018) were grouped into five categories; these include personal, legal, management, cost, and technical for convenience while carrying out analysis (Sun et al. 2017). Sun et al. (2017) compiled a total of twenty-two BIM adoption barriers; however, that does not necessarily apply to the entire professional fields, organizations, and countries as common. For example, the UK reported 18 barriers in their continuous BIM assessment survey (NBS 2018, p. 35), and these barriers are not exactly as those extracted by Sun et al. (2017) or those by Wang (2015). Though, there are some similarities and common terms across the lists. For example, Khosrowshahi and Arayici (2012) reported many barriers to adopt BIM across the UK, and assert that those barriers are commonly on organizational readiness. Table 1 summarizes the compiled barriers to BIM adoption from across organizations and countries. 
Table 1: Barriers to BIM adoption

\begin{tabular}{|c|c|c|}
\hline S/No. & $\begin{array}{l}\text { Barriers to BIM } \\
\text { adoption }\end{array}$ & Reference \\
\hline 1 & $\begin{array}{l}\text { Lack of expertise } \\
\text { within the organizations }\end{array}$ & $\begin{array}{l}\text { Aouad et al., 2006; Yan and Damian, 2008; Arayici } \\
\text { et al., 2009; Lindblad, 2013; Wang et al., 2015; } \\
\text { Saleh, 2015; Ahmed et al., 2018; Jamal et al., 2019; } \\
\text { Tan et al., } 2019\end{array}$ \\
\hline 2 & $\begin{array}{l}\text { Lack of expertise } \\
\text { within the project } \\
\text { team }\end{array}$ & $\begin{array}{l}\text { Saleh, 2015; Wang et al., 2015; Jamal et al., 2019; } \\
\text { Tan et al., } 2019\end{array}$ \\
\hline 3 & $\begin{array}{l}\text { Lack of standardization } \\
\text { and protocols }\end{array}$ & $\begin{array}{l}\text { BCIS, 2011; Wang et al., 2015; Ahmed et al., 2018; } \\
\text { Jamal et al., 2019; Tan et al., } 2019\end{array}$ \\
\hline 4 & $\begin{array}{l}\text { Lack of collaboration } \\
\text { among stakeholders }\end{array}$ & BCIS, 2011; Wang et al., 2015; Tan et al., 2019 \\
\hline 5 & High Investment Cost & $\begin{array}{l}\text { Yan and Damian, 2008; Coates et al., 2010; Giel et } \\
\text { al., 2010; Thompson and Miner, 2010; Azhar, } \\
\text { 2011; Efficiency and Reform Group, 2011; Lee et } \\
\text { al., 2012; Crotty, } 2012\end{array}$ \\
\hline 6 & $\begin{array}{l}\text { Legal issues around } \\
\text { ownership, IP \& PI } \\
\text { insurance }\end{array}$ & $\begin{array}{l}\text { Christensen et al., 2007; Furneaux and Kivvits, } \\
\text { 2008; Arayici et al., 2009; Chao-Duivis, 2009; } \\
\text { Azhar, 2011; Oluwole, 2011; UK BIM Industry } \\
\text { Working Group, 2011; Udom, 2012; Race, 2012; } \\
\text { Jamal et al., 2019; }\end{array}$ \\
\hline 7 & Lack of client demand & $\begin{array}{l}\text { BCIS 2011; Zuhairi et al. 2014; Saleh, 2015; Wang } \\
\text { et al., 2015; Jamal et al., } 2019\end{array}$ \\
\hline 8 & Lack of infrastructure & Wang et al., 2015 \\
\hline 9 & $\begin{array}{l}\text { Lack of government } \\
\text { policy }\end{array}$ & Wang et al., 2015; Elhendawi, A.I.N., 2018 \\
\hline 10 & $\begin{array}{l}\text { Industry's Cultural } \\
\text { resistance }\end{array}$ & $\begin{array}{l}\text { Jordani, 2008; Mihindu and Arayici, 2008; Yan and } \\
\text { Damian, 2008; Rowlinson et al, 2009; Watson, } \\
\text { 2010; Arayici et al., } 2011\end{array}$ \\
\hline 11 & $\begin{array}{l}\text { Lack of additional } \\
\text { project finance to } \\
\text { support BIM }\end{array}$ & Arayici et al., 2009; Jamal et al., 2019 \\
\hline 12 & $\begin{array}{l}\text { Resistance at the } \\
\text { operational level }\end{array}$ & Jamal et al., 2019 \\
\hline 13 & $\begin{array}{l}\text { The reluctance of team } \\
\text { members to share } \\
\text { information }\end{array}$ & $\begin{array}{l}\text { Yan and Damian, 2008; Arayici et al., 2009; Wang } \\
\text { et al., } 2015\end{array}$ \\
\hline 14 & $\begin{array}{l}\text { Return on Investment } \\
\text { (ROI) issue }\end{array}$ & $\begin{array}{l}\text { Coates et al., 2010; Arayici et al., 2011; Lee et al., } \\
2012\end{array}$ \\
\hline
\end{tabular}

The lack of expertise, training and cost of the tools are consistently remaining amongst the significant barriers to BIM adoption across some countries. Countries like the UK (NBS, 
2018; NBS, 2017 NBS, 2013), Malaysia (Jamal et al., 2019) and Nigeria (Wang, 2015; Onungwa et al., 2017; Abubakar et al., 2014) are examples of that. In the UK, a lack of expertise is attributed to the low performance of the Higher Education Institutions (HEIs). Moreover, the low levels of engagement between the HEIs and the industry appear the major issue (Underwood et al., 2015). While in Nigeria, students are generally trained on 'file-based collaboration' - 2D and 3D CAD and HEIs are not technically ready to offer the BIM training at all (Hamma-adama et al., 2018).

The drivers to adopt innovation are merely the facilitators to adopt a new product or process (Saleh, 2015). The facilitators are the enablers as resolving the barriers ease the adoption of innovation; the same way the drivers support the adoption process. Potential drivers mostly fall under empowerment, leadership, and creative culture; and most barriers are interlinked with drivers. In most circumstances, the motivator is achieved by removal of a barrier. For example, resolving the lack of experts or trained personnel on BIM means providing training on BIM. Table 2 below summarizes some potential drivers from previous studies.

Table 2: Drivers to BIM adoption

\begin{tabular}{|c|c|c|}
\hline S/No. & $\begin{array}{l}\text { Drivers to BIM } \\
\text { adoption }\end{array}$ & Reference \\
\hline 1 & $\begin{array}{l}\text { Availability of trained } \\
\text { professionals to handle the } \\
\text { tools }\end{array}$ & $\begin{array}{l}\text { McDonald, 2012; Kiani et al., 2015; Saleh, 2015; } \\
\text { Badrinath et al., } 2016\end{array}$ \\
\hline 2 & BIM Software affordability & Oladapo, 2007; Macdonald, 2012; Eadie et al., 2013 \\
\hline 3 & $\begin{array}{l}\text { Enabling environment within } \\
\text { the industry }\end{array}$ & Oladapo, 2007; Takim et al., 2013 \\
\hline 4 & $\begin{array}{l}\text { Clients' interest in the use of } \\
\text { BIM in their projects }\end{array}$ & $\begin{array}{l}\text { Liu et al., 2010; BCIS 2011; Eadie et al., 2013; Lee \& Yu, } \\
\text { 2013; Takim et al., 2013; Saleh, } 2015\end{array}$ \\
\hline 5 & $\begin{array}{l}\text { Awareness of the technology } \\
\text { among industry stakeholders }\end{array}$ & Oladapo, 2007; Zikic, 2009; Saleh, 2015 \\
\hline 6 & $\begin{array}{l}\text { Cooperation and commitment } \\
\text { of professional bodies to its } \\
\text { implementation }\end{array}$ & Oladapo, 2007; Becerik-Gerber et al., 2011 \\
\hline 7 & $\begin{array}{l}\text { Proof of cost savings by its } \\
\text { adoption }\end{array}$ & $\begin{array}{l}\text { Newton \& Chileshe, 2012; Eadie et al., 2013; } \\
\text { Demirdoven, 2015; Saleh, } 2015\end{array}$ \\
\hline 8 & $\begin{array}{l}\text { Cultural change among } \\
\text { industry stakeholders }\end{array}$ & Kiani et al., 2015; Saleh, 2015 \\
\hline 9 & $\begin{array}{l}\text { Government support through } \\
\text { legislation }\end{array}$ & $\begin{array}{l}\text { Efficiency and Reform Group, 2011; buildingSMART } \\
\text { Australasia, 2012; Eadie et al., 2013; Zuhairi et al., 2014; } \\
\text { Kiani et al., 2015; Saleh, 2015; Natalija et al., 2019 }\end{array}$ \\
\hline 10 & $\begin{array}{l}\text { Collaborative Procurement } \\
\text { methods }\end{array}$ & Sinclair, 2012 \\
\hline
\end{tabular}




\section{Research Methodology:}

A literature review was adopted in identifying potential barriers and drivers for BIM adoption. That serves as precedent and baseline to the study; primary data is also involved in this study and was collected within five months period. An online questionnaire survey was used as a tool for data collection. To determine the target population, interested parties were quite insignificant as the study subject awareness appears low (Hamma-adama et al., 2018b). A mixture of purposeful sampling and snowball method was adopted in the sampling and data collection procedure. The purposeful sampling was adopted to allow the researcher selects only the participants who possess the qualities necessary to provide meaningful input and reliable assessment of the study context (Coyne, 1997); and snowball was utilized in generating substantial (in both quality and quantity) responses (Noy, 2008). The purposeful sampling is adopted because; only those who are aware of or have knowledge of BIM are of interest in this study.

A quantitative research approach is adopted. A quantitative research method is used in achieving a wide coverage of the survey with a considerable response rate, bias freeresponse and free from privacy issues (Naoum, 2012). A structured questionnaire survey was used for the primary data collection. The questionnaire was designed mainly on two target enquiries, drivers and barriers to adoption of BIM in the Nigerian construction industry after determination of the respondent's demography. As it is set for a purpose, only those aware of BIM responses are accepted; thus, the system accepts the only target audience.

A reliability test, descriptive statistics and Relative Importance Index (RII) were subsequently deployed in the analysis of data. The reliability test was carried out in ascertaining the internal consistency of the scale of items used in the questionnaire. Descriptive statistics and RII were used in the determination of the most influential items for both adopters and non-adopters.

As for the respondents' profile, categorical data is generated while the main questions involved the use of a five-point Likert rating scale with five as the highest rank and one as the lowest. A five-point Likert rating scale is used with a standard method of ranking using Relative Importance Index (RII).

The relationship defines RII as:

Relative Importance Index $(\mathrm{RII})=\Sigma \mathrm{W}(0 \leq$ index $\leq 1)($ Eadie et al., 2013)

$$
\overline{\mathrm{A} \times \mathrm{N}}
$$

where:

$\mathrm{W}=$ element weighting by the respondents using a number between 1 and 5 . Considering 1 as the least significant variable, and 5 as the most significant variable;

$\mathrm{A}=$ highest weight; and 
$\mathrm{N}=$ total number of respondents.

Subsequently, the BIM barriers and BIM drivers ranked by the respondents are examined in terms of their interaction with the BIM concept. Some have already adopted the concept, while some are still at the awareness stage. A comparison was carried out using the Rank Agreement Factor (RAF) to determine adopters and non-adopters level of agreement or disagreement to the respective rankings by the group of adopters and nonadopters.

The following relationships define RAF:

And, maximum RAF (RAFmax) is then evaluated with:

Where;

$\mathrm{Ri}, 1$ is the rank of item $\mathrm{i}$ in group 1 ,

$\mathrm{Ri}, 2$, is the rank of item $\mathrm{i}$ in group 2,

$\mathrm{N}$ is the total number of items, which is the same for each group,

$\mathrm{Rj}, 2$ is the rank of item $\mathrm{j}$ in group 2 , and;

$\mathrm{j}=\mathrm{N}-\mathrm{i}+1$.

Percentage Disagreement (PD) between the two groups is the ratio of RAF to RAFmax, as expressed below:

While the Percentage Agreement (PA) between the two ranked groups is the balance of percentage from the $\mathrm{PD}$, which is:

$\mathrm{PA}=100-\mathrm{PD}$

A higher RAF value indicates a weaker agreement between the two groups. Thus, the RAF value of zero means a complete agreement between two subject groups. A spider diagram is plotted as in Fig. 3 and 4 to graphically illustrate the ranking variations by the two set groups.

\section{Data collected, results and discussions:}

The reliability test result, respondents' demographic information, descriptive statistics on the barriers and the drivers as well as the important relative index are evaluated and presented below.

\subsection{Reliability test}

The reliability test is carried out to ascertain an internal consistency of the scale of items used in the questionnaire as well as the reliability of the questionnaire for further analysis. Thus, Cronbach's Alpha is adopted for the reliability analysis, and the results are compared with George \& Malley's (2003) acceptability. Any coefficient of Cronbach's alpha that is greater than 0.6 is considered acceptable, as such, all the items are within acceptable limit with Cronbach's Alpha coefficient of 0.95 (see Table 3 and 4). Moreover, all values $>0.7$ are considered acceptable according to Pallant (2013); thus, Cronbach's alpha $>0.9$ 
indicated a high level of internal consistency of the measured items and mean values they are closely related.

Table 3: Reliability Test

\begin{tabular}{|c|c|c|c|c|}
\hline \multicolumn{5}{|l|}{ Item-Total Statistics } \\
\hline & $\begin{array}{c}\text { Scale } \\
\text { Mean if } \\
\text { Item } \\
\text { Deleted }\end{array}$ & $\begin{array}{c}\text { Scale } \\
\text { Variance } \\
\text { if Item } \\
\text { Deleted }\end{array}$ & $\begin{array}{l}\text { Corrected } \\
\text { Item-Total } \\
\text { Correlation }\end{array}$ & $\begin{array}{l}\text { Cronbac } \\
\text { h's } \\
\text { Alpha if } \\
\text { Item } \\
\text { Deleted }\end{array}$ \\
\hline $\begin{array}{l}\text { Availability of trained professionals to handle } \\
\text { the tools }\end{array}$ & 75.75 & 396.94 & .68 & .95 \\
\hline BIM Software affordability & 76.09 & 396.80 & .65 & .95 \\
\hline Enabling environment within the industry & 76.18 & 399.70 & .69 & .95 \\
\hline $\begin{array}{l}\text { Clients interest in the use of BIM in their } \\
\text { projects }\end{array}$ & 76.15 & 391.14 & .68 & .95 \\
\hline $\begin{array}{l}\text { Awareness of the technology among industry } \\
\text { stakeholders }\end{array}$ & 76.09 & 404.95 & .59 & .95 \\
\hline $\begin{array}{l}\text { Cooperation and commitment of professional } \\
\text { bodies to its implementation }\end{array}$ & 76.16 & 397.78 & .68 & .95 \\
\hline Proof of cost savings by its adoption & 75.94 & 406.62 & .55 & .95 \\
\hline Cultural change among industry stakeholders & 76.54 & 402.52 & .65 & .95 \\
\hline Government support through legislation & 76.51 & 389.18 & .75 & .95 \\
\hline Collaborative Procurement methods & 76.46 & 394.25 & .72 & .95 \\
\hline Lack of expertise within the organizations & 75.79 & 406.29 & .52 & .95 \\
\hline Lack of expertise within the project team & 75.97 & 402.78 & .58 & .95 \\
\hline Lack of standardization and protocols & 76.04 & 397.71 & .69 & .95 \\
\hline Lack of collaboration among stakeholders & 76.26 & 398.23 & .70 & .95 \\
\hline High Investment Cost & 76.35 & 393.81 & .71 & .95 \\
\hline $\begin{array}{l}\text { Legal issues around ownership, IP \& PI } \\
\text { insurance }\end{array}$ & 76.69 & 397.38 & .68 & .95 \\
\hline Lack of client demand & 76.21 & 398.20 & .59 & .95 \\
\hline Lack of infrastructure & 76.40 & 394.21 & .67 & .95 \\
\hline Lack of government policy & 76.24 & 391.41 & .71 & .95 \\
\hline Industry's Cultural resistance & 76.31 & 401.95 & .64 & .95 \\
\hline $\begin{array}{l}\text { Lack of additional project finance to support } \\
\text { BIM }\end{array}$ & 76.24 & 394.84 & .72 & .95 \\
\hline Resistance at the operational level & 76.62 & 405.82 & .57 & .95 \\
\hline $\begin{array}{l}\text { The reluctance of team members to share } \\
\text { information }\end{array}$ & 76.26 & 398.74 & .75 & .95 \\
\hline Return on Investment (ROI) issue & 76.60 & 401.86 & .64 & .95 \\
\hline
\end{tabular}

Table 4: Reliability Alpha Value

\begin{tabular}{|c|c|}
\hline \multicolumn{2}{|c|}{ Reliability Statistics } \\
\hline $\begin{array}{c}\text { Cronbach's } \\
\text { Alpha }\end{array}$ & $\mathrm{N}$ of Items \\
\hline .95 & 24 \\
\hline
\end{tabular}




\subsection{Demographic profile of respondents}

Table 5 presents the details of the respondents participated in the study or survey. The details include their location of practice in Nigeria, years of experience in the industry, size of their organizations, profession, specialization and their highest educational qualification.

Table 5: Analysis of socio-economic variables (Source: field survey, 2018.)

\begin{tabular}{|c|c|c|c|c|}
\hline Variable & Characteristics & Freq. & $\begin{array}{c}\text { Percentage } \\
(\%)\end{array}$ & Total \\
\hline \multirow{6}{*}{$\begin{array}{l}\text { Location of } \\
\text { practice }\end{array}$} & North-Central & 26 & 38.2 & \\
\hline & North-East & 11 & 16.2 & \\
\hline & North-West & 16 & 23.5 & \\
\hline & South-East & 2 & 2.9 & \\
\hline & South-South & 4 & 5.9 & \\
\hline & South-West & 9 & 13.2 & 68 \\
\hline \multirow{4}{*}{$\begin{array}{l}\text { Years of } \\
\text { practice }\end{array}$} & $<5$ years & 14 & 20.6 & \\
\hline & $5-10$ years & 27 & 39.7 & \\
\hline & $11-15$ years & 15 & 22.1 & \\
\hline & $>15$ years & 12 & 17.6 & 68 \\
\hline \multirow{4}{*}{$\begin{array}{l}\text { Number of } \\
\text { employees }\end{array}$} & $<10$ personnel (Micro) & 29 & 42.6 & \\
\hline & 10 - 50 personnel (Small) & 29 & 42.6 & \\
\hline & 50 - 200 personnel (Medium) & 7 & 10.3 & \\
\hline & $>200$ personnel (Large) & 3 & 4.4 & 68 \\
\hline \multirow[t]{8}{*}{ Profession } & Architecture & 16 & 23.5 & \\
\hline & Building Engineering & 1 & 1.5 & \\
\hline & Civil/Structural Engineering & 30 & 44.1 & \\
\hline & Electrical Engineering & 8 & 11.8 & \\
\hline & Mechanical Engineering & 4 & 5.9 & \\
\hline & Construction Management & 1 & 1.5 & \\
\hline & Quantity Surveying & 7 & 10.3 & \\
\hline & Other: & 1 & 1.5 & 68 \\
\hline \multirow[t]{4}{*}{ Specialization } & Contractor/Construction & 19 & 27.9 & \\
\hline & Designer or Consultant & 41 & 60.3 & \\
\hline & Client & 4 & 5.9 & \\
\hline & Development Authority & 4 & 5.9 & 68 \\
\hline \multirow{4}{*}{$\begin{array}{l}\text { Highest } \\
\text { qualification }\end{array}$} & OND or HND & 2 & 2.9 & \\
\hline & B.Sc./B.Tech./B Eng. & 34 & 50.0 & \\
\hline & MSc/M.Eng. & 25 & 36.8 & \\
\hline & $\mathrm{PhD}$ & 7 & 10.3 & 68 \\
\hline
\end{tabular}

There are considerably higher respondents from four out the six zones, this happened due to a higher number of researchers' network, and a considerable number of firms and construction works within North-Central and South-West specifically. The predominant respondents are having 5 to 15 years of experience in the industry and mostly (about 80\%) 
came from micro (<10 personnel) and small (10 - 50 personnel) firms. In the case of their professions, specialities and educational qualifications, over $60 \%$ of them came from Architectural and Civil/Structural engineering backgrounds and working as designers/consultants and contractors. In addition, more than $80 \%$ are first degree (B.Sc./B.Tech./B.Eng) and second-degree (MSc/M.Eng.) holders.

\subsection{BIM awareness and usage}

This aspect involves the evaluation of the proportion of those using BIM from those aware but not using the concept. Note that all the respondents are only those aware of BIM; whether they use it or not. Thus, the percentages reflect only within the targeted group (who are aware of BIM). A significant shift can be a notice from the 2017 survey, and this indicated a substantial increase in the awareness and usage within the market (see Fig. 1 below). The proportion of users to awareness increased from 28\%:72\% to 54\%:46\% (Fig. 2) based on those aware of BIM.

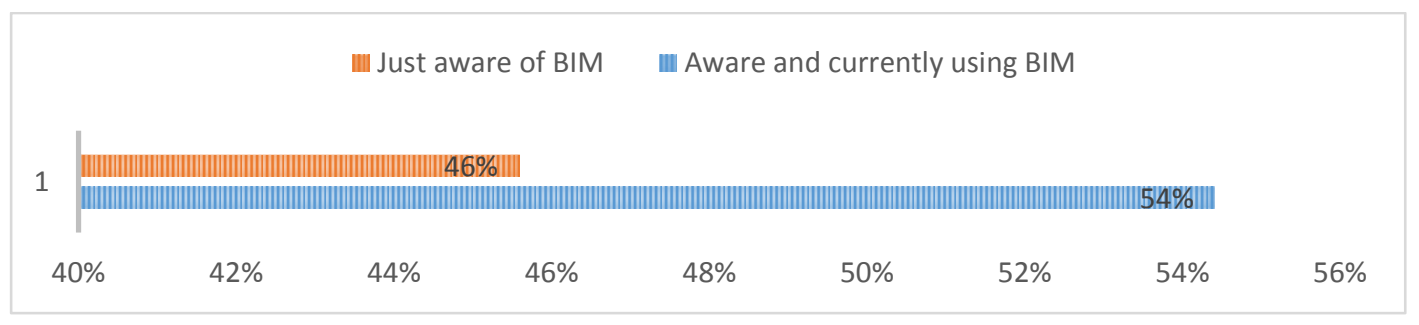

Fig. 1. BIM awareness and usage (Source: field survey, 2018.)

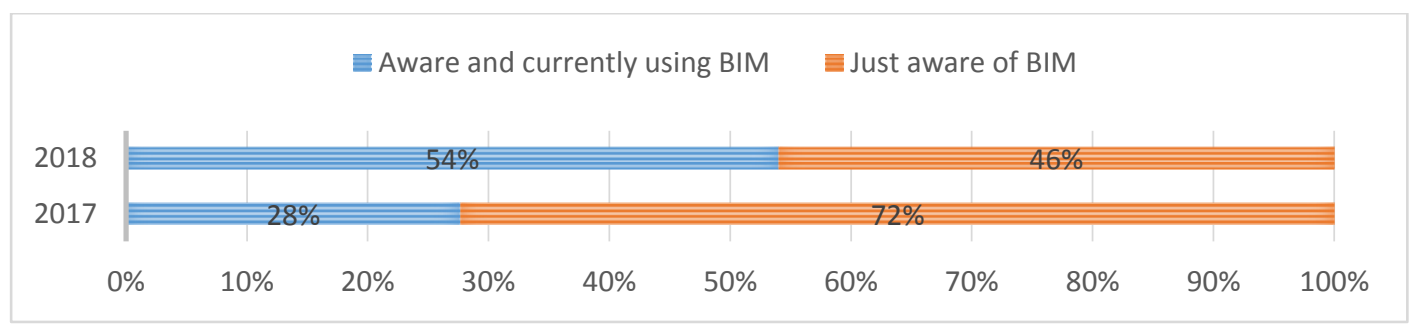

Fig. 2. BIM awareness and usage for 2017 and 2018

\subsection{Barriers to BIM adoption in Nigeria}

Subjecting the fourteen generated barriers to BIM adoption in Nigeria into RII (see table 6 below) using the scale of 1-5 (Likert scale), it is realised that, the 1st ninth-ranked barriers are the most significant $(\mathrm{RII} \geq 0.70$ ) or mean $\geq 3.5$ in a five-point Likert scale (Badu et al., 2012).

The result, in general, indicated lack of expertise within the organizations, lack of expertise within the project team, lack of standardization and protocols, and lack of client 
demand as the most influential barriers (1st to 4th) respectively. Moreover, ranked the following as 5th: lack of government policy, lack of additional project finance to support BIM, lack of collaboration among stakeholders and reluctance of team members to share information.

Table 6: RII and ranking of barriers against BIM adoption in Nigeria

\begin{tabular}{|c|c|c|c|c|c|c|c|c|c|}
\hline $\begin{array}{l}\text { Number of Rank R \& } \\
\text { Weighted value W } \\
\text { impact }\end{array}$ & $\begin{array}{l}\text { Weig } \\
\text { ht } 5\end{array}$ & $\begin{array}{c}\text { Wei } \\
\text { ght } \\
4\end{array}$ & $\begin{array}{c}\text { Wei } \\
\text { ght } \\
3\end{array}$ & $\begin{array}{l}\text { Wei } \\
\text { ght } \\
2\end{array}$ & $\begin{array}{c}\text { Wei } \\
\text { ght } \\
1\end{array}$ & Total & $\Sigma \mathbf{W}$ & RII & Rank \\
\hline $\begin{array}{l}\text { Lack of expertise within } \\
\text { the organizations }\end{array}$ & 110 & 92 & 39 & 10 & 5 & 68 & 256 & $\begin{array}{c}0.7 \\
5\end{array}$ & 1 \\
\hline $\begin{array}{l}\text { Lack of expertise within } \\
\text { the project team }\end{array}$ & 90 & 92 & 42 & 14 & 6 & 68 & 244 & $\begin{array}{c}0.7 \\
2\end{array}$ & 2 \\
\hline $\begin{array}{l}\text { Lack of standardization } \\
\text { and protocols }\end{array}$ & 85 & 76 & 63 & 8 & 7 & 68 & 239 & $\begin{array}{c}0.7 \\
0\end{array}$ & 3 \\
\hline Lack of client demand & 95 & 60 & 42 & 22 & 9 & 68 & 228 & $\begin{array}{c}0.6 \\
7\end{array}$ & 4 \\
\hline Lack of government policy & 85 & 80 & 27 & 24 & 10 & 68 & 226 & $\begin{array}{c}0.6 \\
6\end{array}$ & 5 \\
\hline $\begin{array}{l}\text { Lack of additional project } \\
\text { finance to support BIM }\end{array}$ & 75 & 64 & 63 & 16 & 8 & 68 & 226 & $\begin{array}{c}0.6 \\
6\end{array}$ & 5 \\
\hline $\begin{array}{l}\text { Lack of collaboration } \\
\text { among stakeholders }\end{array}$ & 55 & 88 & 51 & 24 & 6 & 68 & 224 & $\begin{array}{l}0.6 \\
6\end{array}$ & 5 \\
\hline $\begin{array}{l}\text { The reluctance of team } \\
\text { members to share } \\
\text { information }\end{array}$ & 40 & 100 & 57 & 22 & 5 & 68 & 224 & $\begin{array}{c}0.6 \\
6\end{array}$ & 5 \\
\hline $\begin{array}{l}\text { Industry's Cultural } \\
\text { resistance }\end{array}$ & 50 & 80 & 60 & 26 & 5 & 68 & 221 & $\begin{array}{c}0.6 \\
5\end{array}$ & 9 \\
\hline High Investment Cost & 80 & 44 & 60 & 26 & 8 & 68 & 218 & $\begin{array}{c}0.6 \\
4\end{array}$ & 10 \\
\hline Lack of infrastructure & 60 & 84 & 42 & 16 & 13 & 68 & 215 & $\begin{array}{c}0.6 \\
3\end{array}$ & 11 \\
\hline $\begin{array}{l}\text { Return on Investment } \\
\text { (ROI) issue }\end{array}$ & 40 & 48 & 75 & 30 & 8 & 68 & 201 & $\begin{array}{c}0.5 \\
9\end{array}$ & 12 \\
\hline $\begin{array}{l}\text { Resistance at the } \\
\text { operational level }\end{array}$ & 30 & 56 & 81 & 24 & 9 & 68 & 200 & $\begin{array}{c}0.5 \\
9\end{array}$ & 12 \\
\hline $\begin{array}{l}\text { Legal issues around } \\
\text { ownership, IP \& PI } \\
\text { insurance }\end{array}$ & 50 & 36 & 63 & 36 & 10 & 68 & 195 & $\begin{array}{c}0.5 \\
7\end{array}$ & 14 \\
\hline
\end{tabular}

These barriers were analyzed further to balance the perceptions by the BIM adopters and the non-adopters. Table 7 presents the two group rankings. From the first glance on radar plot (Fig. 3), adopters ranking was quite simultaneous, indicating a higher level of reality and consistency. At the same time, non-adopters are a sort of zig-zag manner (ranking whether very high or very low). This pattern suggests that while adopting BIM, perception to barriers change as the realities unfold or became dominant. The barriers ranked 1st, 2nd, 3 rd and 4th by non-adopters, were ranked 2nd, 6th, 9th and 1st by adopters with quite lower average index, as such what is perceived most influential barriers before adoption tend to change after adoption; such challenges may have been dealt with in the adoption process. 
Table 7: Variation of barriers ranking among adopters and non-adopters

\begin{tabular}{|c|c|c|c|c|}
\hline \multirow[t]{2}{*}{ BARRIERS } & \multicolumn{2}{|c|}{ Adopters } & \multicolumn{2}{|c|}{ Non-adopters } \\
\hline & RII & Rank & RII & Rank \\
\hline Lack of standardization and protocols & 0.74 & 1 & 0.66 & 4 \\
\hline Lack of expertise within the organizations & 0.72 & 2 & 0.79 & 1 \\
\hline Industry's Cultural resistance & 0.69 & 3 & 0.60 & 11 \\
\hline $\begin{array}{l}\text { Lack of additional project finance to } \\
\text { support BIM }\end{array}$ & 0.69 & 3 & 0.64 & 9 \\
\hline Lack of client demand & 0.68 & 5 & 0.66 & 4 \\
\hline Lack of expertise within the project team & 0.67 & 6 & 0.77 & 2 \\
\hline Lack of government policy & 0.67 & 6 & 0.66 & 4 \\
\hline Lack of collaboration among stakeholders & 0.66 & 8 & 0.66 & 4 \\
\hline Resistance at the operational level & 0.65 & 9 & 0.52 & 14 \\
\hline $\begin{array}{l}\text { The reluctance of team members to share } \\
\text { information }\end{array}$ & 0.65 & 9 & 0.67 & 3 \\
\hline High Investment Cost & 0.64 & 11 & 0.64 & 8 \\
\hline Lack of infrastructure & 0.63 & 12 & 0.63 & 10 \\
\hline Return on Investment (ROI) issue & 0.59 & 13 & 0.59 & 12 \\
\hline $\begin{array}{l}\text { Legal issues around ownership, IP \& PI } \\
\text { insurance }\end{array}$ & 0.57 & 14 & 0.58 & 13 \\
\hline Average RII & 0.66 & & 0.65 & \\
\hline
\end{tabular}

On the other hand, they quite agreed over half of the barriers as to their significance or indexes. For instance, High Investment Cost, Lack of infrastructure, and Return on Investment (ROI) issue are scored the same magnitude although they were in different ranks. This situation leads to the determination of PD and PA to allow us to drive exclusive findings.

Table 8 presents the evaluation of the PD and PA. The result reveals $49.48 \%$ PD and $50.52 \%$ PA, means both groups have approximately 50:50 agreement to disagreement, in other words, they agreed on half $(50 \%)$ of the ratings and disagreed on the other half (50\%). Conclusively, this indicates that the adopters are still at the infancy stage as their PA is still high (50\%). Higher PA does not go with the findings from (Eadie et al., 2014) that "...BIM adopters change their views on the most significant barriers to BIM after implementation by ranking them differently than those yet to adopt BIM" (Eadie et al., 2014 p. 92). Moreover, the average of 0.66 and 0.65 RII of adopters and non-adopters (respectively) indicated a small difference to their perception of BIM adoption barriers. Thus, confirmed that the country is at the early stage of BIM adoption... 


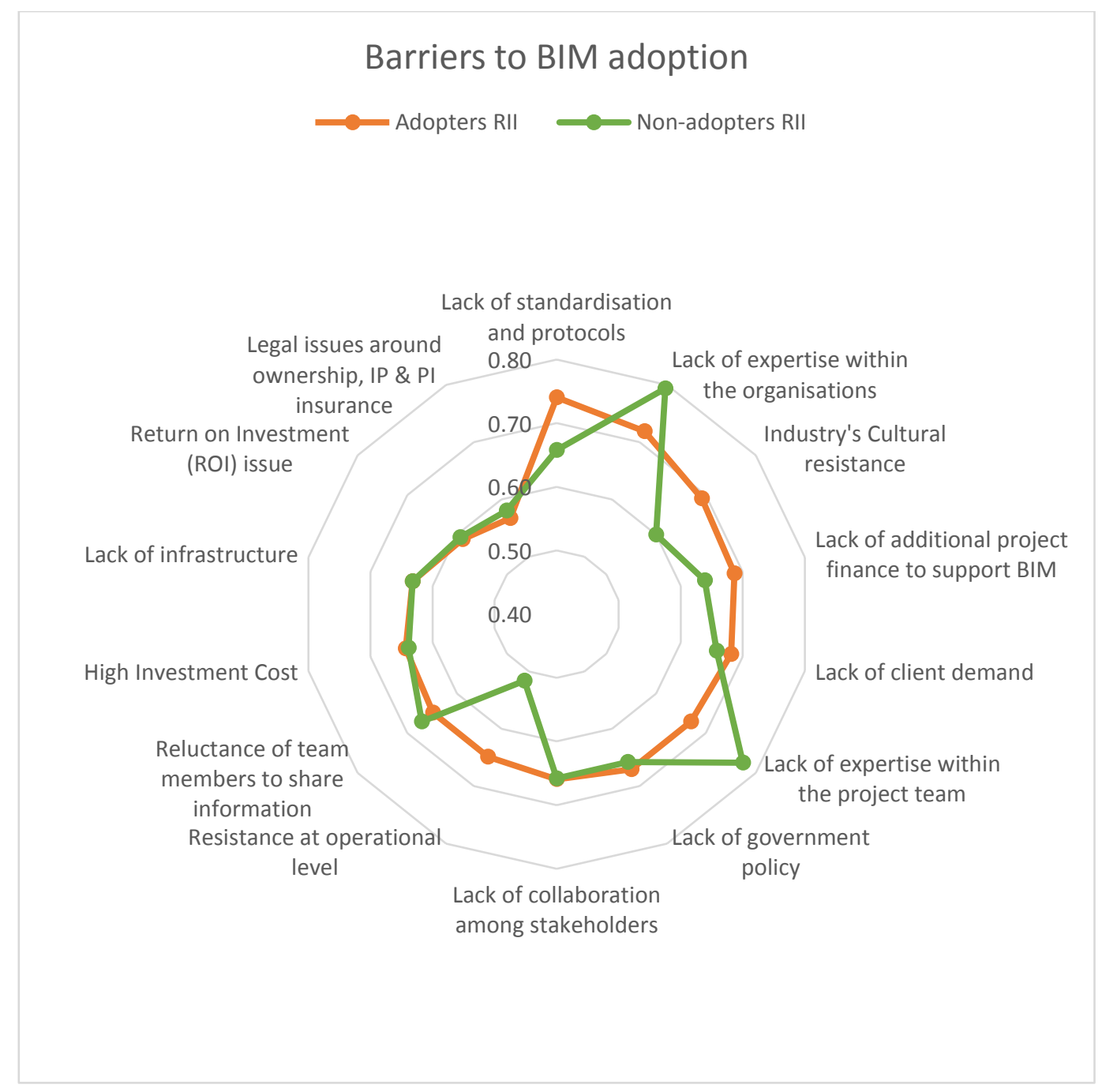

Fig. 3. Variation of barriers ranking among adopters and non-adopters (Source: field survey, 2018.)

Succinctly, nine of the fourteen barriers are significantly crucial to both the adopters and non-adopters; however, the remaining five appeared less important to both groups. These five barriers are resistance at the operational level, high investment cost, lack of infrastructure, return on investment (ROI) issue as well as legal issues around ownership, IP \& PI insurance. 
Table 8: RAF, PD and PA values for BIM barriers

\begin{tabular}{|c|c|c|c|c|c|c|c|}
\hline \multirow{3}{*}{ BARRIERS } & $\begin{array}{c}\text { BIM } \\
\text { Users }\end{array}$ & $\begin{array}{l}\text { BIM } \\
\text { Non- } \\
\text { users }\end{array}$ & & & & & \\
\hline & & & \multicolumn{5}{|c|}{$\mathrm{Rj} 2=\mathrm{Ri} 2$} \\
\hline & $\begin{array}{l}\text { Rank } \\
\text { (Ri1) }\end{array}$ & $\begin{array}{l}\text { Rank } \\
\text { (Ri2) }\end{array}$ & Ri1-Ri2 & $\begin{array}{c}\text { Absolute } \\
\text { of Ri1- } \\
\text { Ri2 }\end{array}$ & $\begin{array}{l}\text { corresponds } \\
\text { to }(\mathrm{N}- \\
\text { Ri1+1) } \\
\text { from Ri1 }\end{array}$ & $\begin{array}{l}\text { Ri1- } \\
\text { Rj2 }\end{array}$ & $\begin{array}{c}\text { Absolute } \\
\text { of Ri1- } \\
\text { Rj2 }\end{array}$ \\
\hline $\begin{array}{l}\text { Lack of standardisation and } \\
\text { protocols }\end{array}$ & 1 & 4 & -3 & 3 & 13 & -12 & 12 \\
\hline $\begin{array}{l}\text { Lack of expertise within the } \\
\text { organisations }\end{array}$ & 2 & 1 & 1 & 1 & 12 & -10 & 10 \\
\hline Industry's Cultural resistance & 3 & 11 & -8 & 8 & 10 & -7 & 7 \\
\hline $\begin{array}{l}\text { Lack of additional project finance } \\
\text { to support BIM }\end{array}$ & 3 & 9 & -6 & 6 & 10 & -7 & 7 \\
\hline Lack of client demand & 5 & 4 & 1 & 1 & 3 & 2 & 2 \\
\hline $\begin{array}{l}\text { Lack of expertise within the } \\
\text { project team }\end{array}$ & 6 & 2 & 4 & 4 & 14 & -8 & 8 \\
\hline Lack of government policy & 6 & 4 & 2 & 2 & 14 & -8 & 8 \\
\hline $\begin{array}{l}\text { Lack of collaboration among } \\
\text { stakeholders }\end{array}$ & 8 & 4 & 4 & 4 & 4 & 4 & 4 \\
\hline Resistance at the operational level & 9 & 14 & -5 & 5 & 2 & 7 & 7 \\
\hline $\begin{array}{l}\text { The reluctance of team members } \\
\text { to share information }\end{array}$ & 9 & 3 & 6 & 6 & 2 & 7 & 7 \\
\hline High Investment Cost & 11 & 8 & 3 & 3 & 9 & 2 & 2 \\
\hline Lack of infrastructure & 12 & 10 & 2 & 2 & 11 & 1 & 1 \\
\hline Return on Investment (ROI) issue & 13 & 12 & 1 & 1 & 1 & 12 & 12 \\
\hline $\begin{array}{l}\text { Legal issues around ownership, IP } \\
\& \text { PI insurance }\end{array}$ & 14 & 13 & 1 & 2 & 4 & 10 & 10 \\
\hline & & & $\begin{array}{l}\text { Absolut } \\
\text { e Sum }\end{array}$ & 48 & & $\begin{array}{l}\text { Absolute } \\
\text { Sum }\end{array}$ & 97 \\
\hline & & & RAF & 3.43 & & $\begin{array}{l}\text { RAF } \\
\text { MAX }\end{array}$ & 6.93 \\
\hline & & & PD & $49.48 \%$ & & PA & $50.52 \%$ \\
\hline
\end{tabular}

\subsection{Drivers to BIM adoption in Nigeria}

Subjecting the ten generated drivers to BIM adoption in Nigeria into RII (see Table 8) using the scale of 1-5 (Likert scale), it was realized that, the 1st seventh-ranked drivers are the most significant (RII $\geq 0.70$ ) or mean $\geq 3.5$ in a five-point Likert scale (Badu et al., 2012). The most influential drivers revealed as availability of trained professionals to handle the tools, proof of cost savings by its adoption, BIM Software affordability and awareness of the technology amongst industry stakeholders (in descending order). Moreover, ranked the following as 5th: clients' interest in the use of BIM in their projects, cooperation and commitment of professional bodies to its implementation, and enabling environment within the industry. 
Table 9: RII and ranking of drivers against BIM adoption in Nigeria

\begin{tabular}{|c|c|c|c|c|c|c|c|c|c|}
\hline $\begin{array}{l}\text { Number of Rank } R \& \text { Weighted } \\
\text { value } W \text { impact }\end{array}$ & $\begin{array}{c}\text { Weight } \\
5\end{array}$ & $\begin{array}{c}\text { Weight } \\
4\end{array}$ & $\begin{array}{c}\text { Weight } \\
\mathbf{3}\end{array}$ & $\begin{array}{c}\text { Weight } \\
2\end{array}$ & $\begin{array}{c}\text { Weight } \\
1\end{array}$ & Total & $\sum \mathbf{W}$ & RII & Rank \\
\hline $\begin{array}{l}\text { Availability of trained professionals } \\
\text { to handle the tools }\end{array}$ & 130 & 84 & 24 & 16 & 5 & 68 & 259 & 0.76 & 1 \\
\hline $\begin{array}{l}\text { Proof of cost savings by its } \\
\text { adoption }\end{array}$ & 85 & 88 & 57 & 12 & 4 & 68 & 246 & 0.72 & 2 \\
\hline BIM Software affordability & 90 & 84 & 36 & 18 & 8 & 68 & 236 & 0.69 & 3 \\
\hline $\begin{array}{l}\text { Awareness of the technology } \\
\text { among industry stakeholders }\end{array}$ & 70 & 84 & 57 & 22 & 3 & 68 & 236 & 0.69 & 3 \\
\hline $\begin{array}{l}\text { Clients interest in the use of BIM in } \\
\text { their projects }\end{array}$ & 115 & 48 & 45 & 12 & 12 & 68 & 232 & 0.68 & 5 \\
\hline $\begin{array}{l}\text { Cooperation and commitment of } \\
\text { professional bodies to its } \\
\text { implementation }\end{array}$ & 80 & 72 & 48 & 26 & 5 & 68 & 231 & 0.68 & 5 \\
\hline $\begin{array}{l}\text { Enabling environment within the } \\
\text { industry }\end{array}$ & 60 & 92 & 48 & 26 & 4 & 68 & 230 & 0.68 & 5 \\
\hline Collaborative Procurement methods & 45 & 84 & 54 & 16 & 12 & 68 & 211 & 0.62 & 8 \\
\hline $\begin{array}{l}\text { Government support through } \\
\text { legislation }\end{array}$ & 65 & 64 & 42 & 22 & 14 & 68 & 207 & 0.61 & 9 \\
\hline $\begin{array}{l}\text { Cultural change among industry } \\
\text { stakeholders }\end{array}$ & 20 & 92 & 54 & 32 & 7 & 68 & 205 & 0.60 & 10 \\
\hline
\end{tabular}

These drivers were analyzed further to balance the perceptions by both the adopters and non-adopters. Table 10 presents the two group rankings. From the first glance on radar plot (Fig. 4), the adopters ranking was simultaneous, indicating a higher level of reality and consistency. At the same time, the non-adopters are a sort of zigzag at some points (ranking very high and very low). This suggests that while adopting BIM, perception to driving the adoption changes. The drivers ranked $1 \mathrm{st}, 2 \mathrm{nd}, 3 \mathrm{rd}$ and 4 th by the non-adopters are ranked 1st, 8th, 5th and 2nd by the adopters. Furthermore, with a tiny difference of average RII as such, what is perceived most influential drivers before adoption tend to change after the adoption.

On the other hand, the average RII of 0.68 and 0.67 for the adopters and the non-adopters respectively revealed that the adopters are still at an early stage, so they perceive the drivers' influence the same way with the non-adopters.

Table 10: Variation of drivers ranking among adopters and non-adopters

\begin{tabular}{lcccc}
\hline DRIVERS & \multicolumn{2}{c}{ Adopters } & \multicolumn{2}{c}{ Non-adopters } \\
\hline & RII & Rank & RII & Rank \\
Availability of trained professionals to & 0.76 & 1 & 0.77 & 1 \\
handle the tools & 0.74 & 2 & 0.70 & 4 \\
$\begin{array}{l}\text { Proof of cost savings by its adoption } \\
\text { Clients interest in the use of BIM in their }\end{array}$ & 0.70 & 3 & 0.66 & 6 \\
projects & 0.69 & 4 & 0.66 & 6 \\
$\begin{array}{l}\text { Enabling environment within the industry } \\
\text { Awareness of the technology among }\end{array}$ & 0.68 & 5 & 0.71 & 3 \\
$\begin{array}{l}\text { industry stakeholders } \\
\text { Cooperation and commitment of } \\
\text { professional bodies to its implementation }\end{array}$ & 0.68 & 5 & 0.68 & 5 \\
$\begin{array}{l}\text { Cultural change among industry } \\
\text { stakeholders }\end{array}$ & 0.66 & 7 & 0.54 & 10 \\
\hline
\end{tabular}




\begin{tabular}{lcccc}
\hline BIM Software affordability & 0.65 & 8 & 0.74 & 2 \\
Collaborative Procurement methods & 0.65 & 8 & 0.59 & 8 \\
Government support through legislation & 0.61 & 10 & 0.61 & 8 \\
Average RII & $\mathbf{0 . 6 8}$ & & $\mathbf{0 . 6 7}$ & \\
\hline
\end{tabular}

Notwithstanding, they nearly have the same average RII, the adopters disagree a bit more than they agree with the non-adopters in terms of individual drivers' influence to adopt BIM (Table 10). To demonstrating this scenario, availability of trained professionals to handle the BIM tools, cooperation and commitment of professional bodies to BIM implementation and Government support through legislation are drivers that scored the same and rated the same to moving the adoption further by both the adopters and nonadopters. This finding suggests persistent investment on the drivers to drive the BIM adoption further.

Table 10 presents the evaluation of the PD and PA. The result reveals more justification of early adoption stage as shown by the study on the barriers. The PD is found to be $58.82 \%$, and the PA is $41.18 \%$. It means both groups have nearly 40:60 agreement to disagreement; in other words, they agreed on 4 out of $10(40 \%)$ of the drivers' scoring and disagreed on the remaining 6 out of the $10(60 \%)$ drivers' scoring.

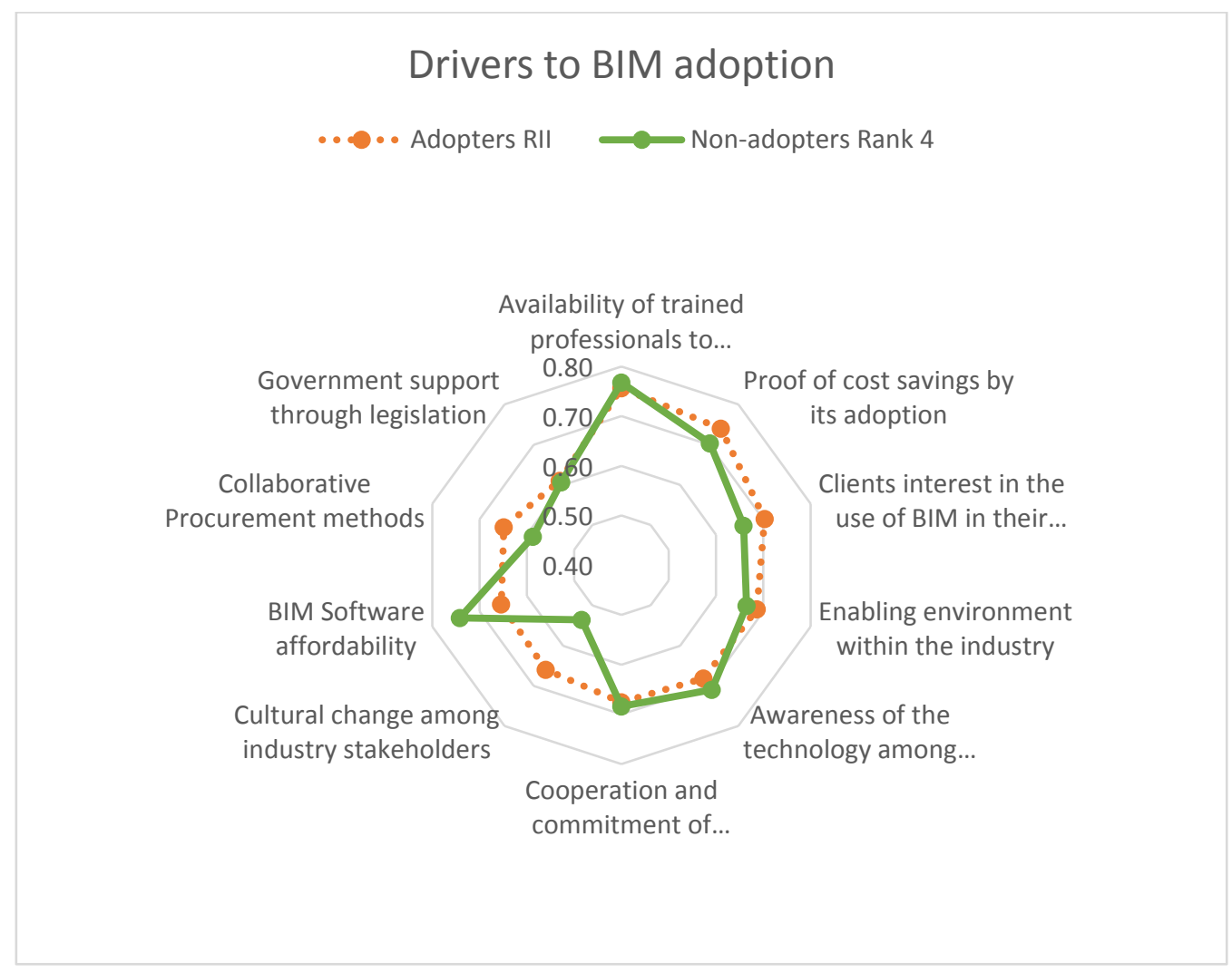

Fig. 4. Variation of drivers ranking among adopters and non-adopters (Source: field survey, 2018.) 
Succinctly, all the drivers are of high importance to both the adopters and non-adopters in the exception of three who appear less compared to the rest. These three drivers are cultural change among industry stakeholders, collaborative procurement methods and government support through legislation.

Table 10: RAF, PD and PA values for BIM Drivers

\begin{tabular}{|c|c|c|c|c|c|c|c|}
\hline \multirow[b]{2}{*}{ DRIVERS } & $\begin{array}{c}\text { BIM } \\
\text { Users }\end{array}$ & $\begin{array}{l}\text { BIM } \\
\text { Non- } \\
\text { users }\end{array}$ & & & & & \\
\hline & $\begin{array}{c}\text { Rank } \\
(\mathrm{R} 1)\end{array}$ & $\begin{array}{c}\text { Rank } \\
(\mathrm{R} 2)\end{array}$ & $\mathrm{R} i 1-\mathrm{R} i 2$ & $\begin{array}{l}\text { Absolute } \\
\text { of Ri1- } \\
\text { Ri2 }\end{array}$ & $\begin{array}{c}\mathrm{R} j 2=\mathrm{R} i 2 \\
\text { corresponds } \\
\text { to (N- } \\
\mathrm{R} i 1+1) \text { from } \\
\mathrm{R} i 1\end{array}$ & $\mathrm{R} i 1-\mathrm{Rj} 2$ & $\begin{array}{l}\text { Absolute } \\
\text { of Ri1- } \\
\text { Rj2 }\end{array}$ \\
\hline $\begin{array}{l}\text { Availability of trained } \\
\text { professionals to handle the } \\
\text { tools }\end{array}$ & 1 & 1 & 0 & 0 & 8 & -7 & 7 \\
\hline $\begin{array}{l}\text { Proof of cost savings by its } \\
\text { adoption }\end{array}$ & 2 & 4 & -2 & 2 & 8 & -6 & 6 \\
\hline $\begin{array}{l}\text { Clients interest in the use of } \\
\text { BIM in their projects }\end{array}$ & 3 & 6 & -3 & 3 & 2 & 1 & 1 \\
\hline $\begin{array}{l}\text { Enabling environment within } \\
\text { the industry }\end{array}$ & 4 & 6 & -2 & 2 & 10 & -6 & 6 \\
\hline $\begin{array}{l}\text { Awareness of the technology } \\
\text { among industry stakeholders }\end{array}$ & 5 & 3 & 2 & 2 & 5 & 0 & 0 \\
\hline $\begin{array}{l}\text { Cooperation and commitment } \\
\text { of professional bodies to its } \\
\text { implementation }\end{array}$ & 5 & 5 & 0 & 0 & 5 & 0 & 0 \\
\hline $\begin{array}{l}\text { Cultural change among } \\
\text { industry stakeholders }\end{array}$ & 7 & 10 & -3 & 3 & 6 & 1 & 1 \\
\hline BIM Software affordability & 8 & 2 & 6 & 6 & 6 & 2 & 2 \\
\hline $\begin{array}{l}\text { Collaborative Procurement } \\
\text { methods }\end{array}$ & 8 & 8 & 0 & 0 & 6 & 2 & 2 \\
\hline $\begin{array}{l}\text { Government support through } \\
\text { legislation }\end{array}$ & 10 & 8 & 2 & 2 & 1 & 9 & 9 \\
\hline & & & $\begin{array}{l}\text { Absolute } \\
\text { Sum }\end{array}$ & 20 & & $\begin{array}{l}\text { Absolute } \\
\text { Sum }\end{array}$ & 34 \\
\hline & & & RAF & 2.00 & & $\begin{array}{l}\text { RAF } \\
\text { MAX }\end{array}$ & 3.40 \\
\hline & & & PD & $58.82 \%$ & & PA & $41.18 \%$ \\
\hline
\end{tabular}

\section{Conclusions:}

The urgent need for BIM adoption in construction industry is providing huge opportunities in research and development. However, researches in barriers and drivers to its adoption did not yield fetched universal adoption thus, that leaves a question of inadequacy or misrepresentations. There are several findings on barriers and drivers to BIM adoption from literatures; many of which having different influence over the other. Nigeria is among developing countries where BIM is becoming vibrant; however, BIM adoption in Nigeria remains in its infancy. This piece of research is aim at filling the gap of differentiating by order of importance, the common barriers vis-a-vis to drivers toward 
BIM adoption in the Nigerian construction market. Fourteen barriers and ten drivers were identified from literature, five Likert scale was used for measurement of respondents' perceptions and RII was used to rank the perceptions. The study revealed that barriers ranked from 1st to 9th are highly influential to the adoption of BIM in Nigeria, and the drivers ranked from 1st to 7 th are significant to facilitate BIM adoption in Nigeria. Further evaluation was carried out in comparing the perception of those adopted BIM and those that have not. Ranking and scoring of barriers and drivers amongst adopters and nonadopters having nearly 50:50 PD to PA which suggests early adoption stage or low maturity stage. The common and most significant barriers and drivers were established from the two set groups. The common and significant barriers to adopters and nonadopters are: Lack of standardization and protocols, Lack of expertise within the organizations, Industry's Cultural resistance, Lack of additional project finance to support BIM, Lack of client demand, Lack of expertise within the project team, Lack of government policy, Lack of collaboration among stakeholders, and Reluctance of team members to share information. On the other hand, the common and most significant drivers to adopters and non-adopters are: Availability of trained professionals to handle the tools, Proof of cost savings by its adoption, Clients interest in the use of BIM in their projects, Enabling environment within the industry, Awareness of the technology among industry stakeholders, Cooperation and commitment of professional bodies to its implementation, and BIM Software affordability.

The study recommends that, to develop effective BIM adoption framework, the established barriers and drivers should be considered vital. The barriers should be resolved in totality, and drivers should be instigated, motivated and encouraged. Further face-toface (interview) study is necessary to explore more and in-depth challenges of BIM adoption in the industry under study; and as the industry is getting more aware of the BIM, periodic evaluation of the critical barriers and drivers is vital. This study contributes to the body of knowledge in providing an in-depth understanding of barriers and drivers from adopters and non-adopters perspectives, their strengths of influence from the two groups and combined influence to adoption of BIM in the Nigerian construction industry.

\section{References:}

[1]. Abubakar, M., Ibrahim, Y. M., Kado, D., \& Bala, K. (2014). Contractors' perception of the factors affecting Building Information Modelling (BIM) adoption in the Nigerian Construction Industry. In Computing in civil and building engineering (2014) (pp. 167-178).

[2]. Ademci, E., \& Gundes, S. (2018). Review of Studies on BIM Adoption in AEC Industry. In 5th international Project and Construction Management Conference (IPCMC2018). Cyprus International University, Faculty of Engineering, Civil Engineering Department, North Cyprus. 
[3]. Ahmed, S., Dlask, P., Selim, O., \& Elhendawi, A. (2018). BIM Performance Improvement Framework for Syrian AEC Companies. International Journal of BIM and Engineering Science, 1(1), 21-41. Available at: http://bimarabia.com/IJBES/

[4]. Aouad, G., Wu, S. and Lee, A. (2007). Advanced technology for quantity surveying, Proceedings of the Quantity Surveyors International Convention, 4th5th September, International Islamic University, Malaysia, pp.313-322.

[5]. Arayici, Y., Coates, P., Koskela, L., Kagioglou, M., Usher, C., O'reilly, K., (2011). Technology adoption in the BIM implementation for lean architectural practice. Autom. ConStruct. 20 (2), 189e195.

[6]. Arayici, Y., Khosrowshahi, F., Marshal Ponting, A. and Mihindu, S., (2009). Towards Implementation of Building Information Modelling in the Construction Industry, Fifth International Conference on Construction in the 21st Century (CITC-V) "Collaboration and Integration in Engineering, Management and Technology” May 20-22, 2009, Istanbul, Turkey.

[7]. Azhar, S. (2011). Building information modelling (BIM): trends, benefits, risks, and challenges for the AEC industry, Leadership and Management in Engineering, Vol. 11 No.3, pp. 241-252.

[8]. Badrinath, A. C., Chang, Y. T. and Hsieh, S. H. (2016). "A review of tertiary BIM education for advanced engineering communication with visualization", Visualization in Engineering, Vol.4 No.9, pp.1-17.

[9]. Badu, E., Edwards, D. J., Owusu-Manu, D., \& Brown, D. M. (2012). Barriers to the implementation of innovative financing (IF) of infrastructure. Journal of Financial Management of Property and Construction, 17(3), 253-273.

[10]. Barnes, P., \& Davies, N. (2014). BIM in Principle and in Practice. London: Institution of Civil Engineers Publishing.

[11]. Becerik-Gerber, B., Gerber, D. J. and Ku, K. (2011). "The pace of technological innovation in architecture, engineering, and construction education: integrating recent trends into the curricula", Journal of Information Technology in Construction, Vol.16, pp.411-432.

[12]. BIM Industry Working Group. (2011). A report for the government construction client group building information modelling (BIM) working party strategy paper. Communications. London, UK.

[13]. Building Cost Information Service BCIS. (2011). Building Information Modelling Survey Report. Royal Institution of Chartered Surveyors RICS.

[14]. buildingSMART Australasia (2012). National building information modelling initiative report, Available online:

http://www.innovation.gov.au/Industry/BuildingandConstruction/BEIIC/Documents /NBIMIReport.pdf (Accessed 20 July 2018).

[15]. Chao-Duivis, M. (2009). Legal Implications of Working with BIM.(Juridische implicaties vanhet werken met BIM), Instituut voor Bouwrecht, Tijdschrift voor Bouwrecht nr. 3, The Hague, March 2009. 44. [in Dutch]. 
[16]. Christensen, S., McNamara, J. and O'Shea, K., (2007). Legal and contracting issues in electronic project administration in the construction industry. Structural Survey, 25(3/4), $191-203$.

[17]. Coates, P., Arayici, Y., Koskela, L. and Usher, C. (2010). The changing perception in the artefacts used in the design practice through BIM adoption, in: CIB 2010, 10/5/10 - 13/5/10, University of Salford UK.

[18]. Coyne, I. T. (1997). Sampling in qualitative research. Purposeful and theoretical sampling; merging or clear boundaries?. Journal of advanced nursing, 26(3), 623630.

[19]. Crotty, R., (2012). The Impact of Building Information Modelling Transforming Construction. 1st ed. Taylor and Francis, London, UK.

[20]. Eadie R, Browne M, Odeyinka H, McKeown C, McNiff S. (2013). BIM implementation throughout the UK construction project lifecycle: An analysis. Autom Constr.36:145-151.

[21]. Eadie, R., Odeyinka, H., Browne, M., McKeown, C., \& Yohanis, M. (2014). Building information modelling adoption: an analysis of the barriers to implementation. Journal of Engineering and Architecture, 2(1), 77-101.

[22]. Efficiency and Reform Group,(2011). Government Construction Strategy, Cabinet Office, London, $U K$.

[23]. Elhendawi, A., Omar, H., Elbeltagi, E., \& Smith, A. (2019). Practical approach for paving the way to motivate BIM non-users to adopt BIM. International Journal of BIM and Engineering Science, 2(2), pp.01-22.

[24]. Elhendawi, A., Smith, A., \& Elbeltagi, E. (2019). Methodology for BIM implementation in the Kingdom of Saudi Arabia. Methodology, International Journal of BIM and Engineering Science, 2(1).

[25]. Elhendawi, A.I.N., 2018. Methodology for BIM implementation in KSA in AEC industry (Doctoral dissertation, Mansoura University, Egypt).

[26]. Furneaux, C. and Kivvits, R. (2008). BIM - implications for government, CRC for Construction Innovation, Brisbane, Australia.

[27]. George, D. M., \& Mallery, Y. P. (2003). A Simple Guide and Reference. 11.0 Update.

[28]. Giel, B., Issa, R.R.A. and Olbina, S., (2010). Return on investment Analysis of Building Information Modelling in Construction. Nottingham, Nottingham University Press.

[29]. Hamma-adama, M. and Kouider, T. (2019). What are the barriers and drivers toward BIM adoption in Nigeria? In Proceedings of the Creative Construction Conference, $29^{\text {th }}$ June $-2^{\text {nd }}$ July 2019, Budapest, Hungary.

[30]. Hamma-Adama M., Kouider T., Salman H. (2018) Building Information Modeling Uptake: Tool Training in Nigeria. Open Science Journal 3(3).

[31]. Hamma-adama, M., Kouider, T., \& Salman, H. S. (2018b). State of building information modelling (BIM) adoption in Nigeria. In Proceedings of the 34th 
Association of Researchers in Construction Management (ARCOM) annual conference: working papers; a productive relationship; balancing fragmentation and integration, 3-5 September 2018, Belfast, UK.

[32]. Hjelseth, E. (2017). BIM understanding and activities. WIT Transactions on the Built Environment, 169, 3-14.

[33]. Hosseini, M. R., Banihashemi, S., Chileshe, N., Namzadi, M. O., Udeaja, C. E., Rameezdeen, R., \& McCuen, T. (2016). BIM adoption within Australian Small and Medium-sized Enterprises (SMEs): an innovation diffusion model. Construction Economics and Building, 16(3), 71-86.

[34]. Jamal, K. A. A., Mohammad, M. F., Hashim, N., Mohamed, M. R., \& Ramli, M. A. (2019). Challenges of Building Information Modelling (BIM) from the Malaysian Architect's Perspective. In MATEC Web of Conferences (Vol. 266, p. 05003). EDP Sciences.

[35]. Jordani, D. (2008). BIM: A Healthy Disruption to a Fragmented and Broken Process, Journal of Building Information Modelling, Spring 2008, 24-26.

[36]. Khosrowshahi, F., \& Arayici, Y. (2012). Roadmap for implementation of BIM in the UK construction industry. Engineering, Construction and Architectural Management, 19(6), 610-635.

[37]. Kiani, I., Sadeghifam, A. N., Ghomi, S. K., \& Marsono, A. K. B. (2015). Barriers to Implementation of Building Information Modeling in Scheduling and Planning Phase in Iran. Australian Journal of Basic and Applied Sciences, 9(5), 91-97.

[38]. Lee, G., Harrison, K. and Won, J.,(2012). Economic Impact of BIM-Assissted Design Validation. Automation in Construction, 22(1), 577 - 586.

[39]. Lee, S. K., \& Yu, J. H. (2013). Effects of Intrinsic and Extrinsic Motivation Factors on BIM Acceptance. Journal of the Korea Institute of Building Construction, 13(3), 242-252.

[40]. Lindblad, H. (2013). Study of the implementation process of BIM in construction projects.

[41]. Liu, R., Issa, R., \& Olbina, S. (2010, June). Factors influencing the adoption of building information modeling in the AEC Industry. In Proceedings of the International Conference on Computing in Civil and Building Engineering (pp. 139-145).

[42]. Macdonald, J.A (2012). "A framework for collaborative BIM education across the AEC disciplines", proceedings of AUBEA 2012, Sydney, Australia, 4-6th July, pp.223-230.

[43]. McAdam, B. (2010). Building information modelling: the UK legal context. International Journal of Law in the Built Environment, 2(3), 246-259.

[44]. McAuley, B., Hore, A. and West,R. (2016) BICP BIM Global Study, Irish Magazine, Iss 3, 2016, pp 61-65

[45]. Mustaffa, N. E., Salleh, R. M., \& Ariffin, H. L. B. T. (2017, July). Experiences of Building Information Modelling (BIM) adoption in various countries. In 2017 
International Conference on Research and Innovation in Information Systems (ICRIIS) (pp. 1-7). IEEE.

[46]. Naoum, S. (2012). Dissertation research and writing for construction students. Routledge.

[47]. NBS (2013). NBS International BIM Report 2013, Royal Institute of British Architects, RIBA, Enterprises Ltd, London.

[48]. NBS (2017). NBS International BIM Report 2017, Royal Institute of British Architects, RIBA, Enterprises Ltd, London.

[49]. NBS (2018). NBS International BIM Report 2018, Royal Institute of British Architects, RIBA, Enterprises Ltd, London.

[50]. Newton, K., \& Chileshe, N. (2012). Enablers and Barriers of Building Information Modelling (BIM) Within South Australian Construction Organisations (Doctoral dissertation, University of New South Wales).

[51]. Noy, C. (2008). Sampling knowledge: The hermeneutics of snowball sampling in qualitative research. International Journal of social research methodology, 11(4), 327-344.

[52]. Oladapo, A. A. (2007), An investigation into the use of ICT in the Nigerian construction industry, Journal of Information Technology in Construction (ITcon), Vol.12 No. pp. 261-277.

[53]. Oluwole, A. (2011). A preliminary review on the legal implications of BIM and model ownership, Journal of Information Technology in Construction (ITcon), 16, pg. 687-696, available online at http://www.itcon.org/2011/40

[54]. Onungwa, I. O., Uduma-Olugu, N. N. E. Z. I., \& Igwe, J. M. (2017). Building information modelling as a construction management tool in Nigeria. WIT Transactions on The Built Environment, 169, 25-33.

[55]. Pallant, J. (2013). SPSS survival manual. McGraw-Hill Education (UK).

[56]. Race, S., (2012). BIM Demystified. 1st ed. London: RIBA Publishing, UK.

[57]. Rowlinson, S., Collins, R., Tuuli, M. \& Jia, Y., (2009), Implementation of Building Information Modeling (BIM) in Construction: A Comparative Case Study, Proceedings of the 2nd International Symposium on Computational Mechanics and the 12th International Conference on the Enhancement and Promotion of Computational Methods in Engineering and Science, Hong Kong- Macau (China), 30 November-3 December 2009, AIP Conf. Proc. 1233, 572-77.

[58]. Saleh, M. A. D. (2015). Barriers and Driving Factors for Implementing Building Information Modelling (BIM) in Libya (Master's thesis, Eastern Mediterranean University (EMU)-Doğu Akdeniz Üniversitesi (DAÜ)).

[59]. Sinclair, D. (2012). BIM Overlay to the RIBA Outline Plan of Work. Royal Institute of British Architects "RIBA". London, UK.

[60]. Shaban, M.H. and Elhendawi, A., (2018). Building Information Modeling in Syria: Obstacles and Requirements for Implementation. International Journal of BIM and Engineering Science, 1(1). 
[61]. Sun, C., Jiang, S., Skibniewski, M. J., Man, Q., \& Shen, L. (2017). A literature review of the factors limiting the application of BIM in the construction industry. Technological and Economic Development of Economy, 23(5), 764-779.

[62]. Takim, R., Harris, M., \& Nawawi, A. (2013). Building Information Modeling (BIM): A new paradigm for quality of life within Architectural, Engineering and Construction (AEC) industry. Procedia-Social and Behavioral Sciences, 101, 2332.

[63]. Tan, T., Chen, K., Xue, F., \& Lu, W. (2019). Barriers to Building Information Modeling (BIM) implementation in China's prefabricated construction: An interpretive structural modeling (ISM) approach. Journal of Cleaner Production.

[64]. Thompson, D. and Miner, R., (2010). Building Information Modeling - BIM: Contractual Risks are Changing with Technology, Retrieved from http://aepronet.infinityit.com/Guest\%20Essays/GE\%20-\%202006_09\%20\%20Building\%20Information\%20Modeling.pdf

[65]. Udom, K., (2012). Building Information Modelling, Retrieved from http://www.thenbs.com/topics/bim/articles/bimMappingOutTheLegalIssues.asp

[66]. Underwood, J., Ayoade, O., Khosrowshahi, F., Greenwood, D., Pittard, S., \& Garvey, R. (2015, March). Current position and associated challenges of BIM education in UK higher education. In BIM Academic Forum.

[67]. Walasek, D., \& Barszcz, A. (2017). Analysis of the adoption rate of building information modeling [BIM] and its return on investment [ROI]. Procedia Engineering, 172, 1227-1234.

[68]. Wang, C., Adetola, S. H., \& Abdul-Rahman, H. (2015). Assessment of BIM implementation among MEP firms in Nigeria. International Journal of Advances in Applied Sciences, 4(3), 73-81.

[69]. Watson, A. (2010). BIM - A driver for change. Proceedings of the International Conference on Computing in Civil and Building Engineering, (Ed. Tizani, W.), University of Nottingham.

[70]. Yan, H., \& Demian, P. (2008). Benefits and barriers of building information modelling. In: Ren, A., Ma, Z. and Lu, X. Proceedings of the 12th International Conference on Computing in Civil and Building Engineering (ICCCBE XII) \& 2008 International Conference on Information Technology in Construction (INCITE 2008), Beijing, China, 16th-18th October 2008.

[71]. Zikic, N. (2009). Building Information Modeling Uses for Design in the Architecture, Esngineering, and Construction (AEC) Industry. (Doctoral dissertation, Pennsylvania State University).

[72]. Zuhairi, A. H., Marshall-Ponting, A., Ahmad, T. H., Nasly, M. A., \& Zahrizan, Z. (2014). Exploring the barriers and driving factors in implementing Building Information Modelling (BIM) in the Malaysian construction industry- a preliminary study. The Institution of Engineer, Malaysia Journal. 75 (1). 